\title{
Bahan kemoterapeutik sebagai pengontrol plak dan gingivitis
}

\author{
Asdar \\ Bagian Periodonsia \\ Fakultas Kedokteran Gigi Universitas Hasanuddin
}

\begin{abstract}
Plaque control is one of the key elements in dental practice. The proper plaque control facilitates the health return for patients with gingival and periodontal deseases. The concept of using chemical agents to treat such conditions in the mouth has been widely accepted as part of dental practice for hundred of years. Chemotherapeutic agents for local use in the oral cavity are available in many forms over the years. The various product categories and criteria for dental practice are reviewed, and consumer selections are suggested. To date, two agents have been accepted by The American Dental Association (ADA) for treatment of gingivitis: chlorhexidine mouthwash and essential oil mouthwash.
\end{abstract}

Key words: chemotherapeutic agents, plaque, gingivitis, mouthwash

\begin{abstract}
ABSTRAK
Kontrol plak adalah salah satu elemen kunci dalam praktek kedokteran gigi. Kontrol plak yang baik akan memfasilitasi pasien dengan penyakit gusi dan periodontal untuk menjadi sehat. Konsep penggunaan bahan kimia untuk terapi telah digunakan selama bertahuntahun dalam berbagai bentuk. Pada makalah ini dibahas kategori obat dan kriteria penggunaannya bagi praktisi dan panduan pemilihan obat bagi konsumen. Obat kumur resep klorheksidin dan obat kumur non-resep minyak esensial adalah dua jenis obat yang telah diterima oleh American Dental Association (ADA).
\end{abstract}

Kata kunci: bahan kemoterapeutik, plak, gingivitis, obat kumur

Koresponden: Asdar, Bagian Periodonsia, Fakultas Kedokteran Gigi Universitas Hasanuddin, Jl. Kandea No.5 Makassar, Indonesia. 


\section{PENDAHULUAN}

Kebersihan mulut yang baik dapat mengurangi atau menghilangkan timbunan plak pada permukaan gigi, sehinggga dengan sendirinya akan mengurangi kemungkinan terjadinya gingivitis dan penyakit rongga mulut lainnya. Keparahan penyakit radang gusi atau gingivitis akan terus berlanjut akibat penumpukan plak, apabila kebersihan ronggga mulut tidak dipelihara.1

Menyikat gigi dan prosedur pembersihan gigi secara mekanik lainnya dianggap paling efektif dalam mengendalikan plak, mencegah dan mengatasi gingivitis apabila dilakukan dengan menyeluruh dan teratur. Akan tetapi pada kenyataannya banyak individu yang sulit melakukan penyikatan gigi dengan baik, karena kurangnya motivasi dan keterampilan individu untuk melakukan kontrol plak yang akurat, serta pada kondisi tertentu yang menyebabkan individu sulit untuk melakukan kontrol plak secara mekanik dengan baik.2,3 Oleh sebab itu pembersihan gigi secara mekanis perlu dibantu dengan pembersihan secara kimiawi, diantaranya adalah dalam bentuk obat kumur yang dapat mencapai daerah yang tidak dapat dicapai oleh pembersihan gigi secara mekanis.
Kefektifan obat kumur antiplak atau antigingivitis yang tersedia di pasaran masih diragukan oleh profesional kedokteran gigi. Produk-produk ini dianggap terlalu banyak efek sampingnya untuk dikatakan efektif. Kondisi ini mengalami perubahan besar sejak dikeluarkannya standar formal dan syarat-syarat dari Council on Dental Therapeutics dari The American Dental Association (ADA) pada bulan Desember 1985 mengenai bahan antiplak atau antigingivitis. 4

Saat ini banyak sekali bahan kimia yang digunakan dalam obat kumur sebagai bahan pengontrol plak dan gingivitis. Oleh karena itu masalah yang akan diangkat pada karya ilmiah ini adalah sejauh mana keefektivan bahan-bahan kimia yang digunakan sebagai bahan pengontrol plak dan gingivitis.

\section{TINJAUAN PUSTAKA}

Obat-obatan kimia yang digunakan sebagai obat kumur dapat dibedakan berdasarkan cara penggunaannya dan bahan aktifnya. Berdasarkan bahan aktif yang dikandungnya, obat kumur dapat dibedakan atas beberapa golongan, yaitu minyak esensial, triklosan, bisbiguanides, campuran amonia kuartenari, ekstrak tumbuhan - 
sanguinarine, fluoride, povidon-iodine, dan heksetidine.

\section{Minyak esensial}

Bahan kemoterapeutik yang mengandung minyak esensial telah lama digunakan. Penggunaan klinik bahan fenol pertama kali diperkenalkan oleh Joseph Lister pada tahun 1865, dalam bentuk spray untuk antiseptik bedah.4 Produk obat kumur fenol tertua adalah Listerine ${ }^{\circledR}$ yang merupakan kombinasi dari minyak esensial, thymol dan eucalypthol, dicampur dengan mentol dan metil salisilat dalam hidroalkoholik 26,9\%.4 Obat kumur senyawa fenol termasuk obat kumur deodorant dan antiseptik, semula banyak dipakai untuk penyegar napas dan pengobatan sariawan serta infeksi tenggorokan, ternyata kemudian terbukti efektif untuk mencegah pertumbuhan plak supragingiva dan gingivitis.4-6

Mekanisme kerja obat ini adalah merusak dinding sel dan menghambat pembentukan enzim bakteri.5 Contoh lain produk dari obat kumur golongan ini adalah Fresh, yang kandungan bahan-bahannya mirip dengan Listerine.5

Pada suatu penelitian klinik jangka panjang, Listerine terbukti mengurangi akumulasi plak dan keparahan gingivitis.
Diketahui pengurangan plak $20-34 \%$ dan pengurangan gingivitis $28-34 \%$ apabila pasien diinstruksikan untuk berkumur 2 kali dalam satu hari setelah sikat gigi.4 Namun demikian obat kumur jenis ini kurang efektif untuk merawat periodontitis, karena larutan ini tidak dapat mencapai poket periodontal yang dalam.7

Triklosan

Triklosan digunakan dalam sabun mandi, pasta gigi, obat kumur, dan produkproduk kosmetik.4,5 Bahan ini merupakan germisid bisphenol dan non-ionic dengan toksisitas rendah dan aktivitas antibakterial yang luas. 4

Triklosan mempunyai aktivitas melawan jamur dan bakteri mulut, baik gram positif maupun yang gram negatif, termasuk mikroorganisme anaerob. Pada kasus gingivitis ternyata triklosan dapat mengurangi akumulasi dan gingivitis, bakteri aerob dan anaerob dan beberapa jenis actinomyces, juga dapatmengurangi inflamasi yang terjadi pada penyakit periodontal.3 Jenkins dkk, yang dikutip oleh Boel1 melaporkan bahwa kombinasi triklosan $0,1 \%$ dapat menghambat secara bermakna pertumbuhan Streptococcus mutans setelah pemakaian 7 hari. Konsentrasi hambat tumbuh minimalnya adalah $0,001 \%$. 
Mekanisme kerja triklosan dalam menghambat pertumbuhan bakteri adalah bekerja pada dinding sel dan mengganggu peningkatan asam amino dan asam nukleat yang dapat berakibat langsung terhadap sintesis RNA dan protein dari bakteri. Selain itu triklosan dapat melisis bakteri sehingga menjadi sel mati.1

Penelitian terbaru menunjukkan bahwa meskipun memiliki efek entibakterial, namun efek antiplaknya hanyalah sedang. Hal ini mungkin disebabkan oleh pelepasannya dari daerah ikatan dalam rongga mulut terlalu cepat. Oleh karena itu dikembangkanlah suatu formula yang dapat meningkatkan kefektifan produk triklosan ini, yaitu dengan 1) dikombinasikan dengan zinc citrat, untuk menambah potensi antiplak dan anti kalkulusnya, 2) dikombinasikan dengan triklosan dalam kopolimer methocsyetilene dan asam maleik, untuk meningkatkan lamanya retensi, 3) dikombinasikan dengan pyroposphate, untuk meningkatkan sifat antikalkulusnya. Produk-produk ini juga mengandung $0,243 \%$ sodium fluoride/silica untuk memberi efek anti karies.4

\section{Bisbiguanides}

$$
\begin{gathered}
\text { Bisbiguanides merupakan antiseptik } \\
\text { berspektrum luas yang paling luas }
\end{gathered}
$$

digunakan. Pada awalnya bahan ini diperkenalkan dalam bentuk krim antiseptik untuk luka pada kulit, yaitu sebagai larutan antimikroba pembersih luka 4\%. 4,5

Klorheksidin yang merupakan bisbiguanides glukonat, efek antiplaknya dapat mencegah akumulasi plak serta mengurangi keradangan. Adesivitas klorheksidin yang lama pada permukaan gigi, membuat klorheksidin efektif bila digunakan 2 kali dalam satu hari. Pemakaian satu kali dapat mengurangi gingivitis tetapi efek antiplaknya akan berkurang dan sifat prolong retensinya menurun.7 Pada penelitian klinis selama beberapa bulan menunjukkan reduksi plak 45-61\% dan yang lebih penting mengurangi gingivitis 2767\%.3 Contoh obat kumur yang mengandung klorheksidin yaitu Trihexid, Peridex, Corsodyl, dan Minosep.7

Keuntungan lain bahan ini berasal dari segi sifat bahan itu sendiri yaitu ikatannya yang lama pada berbagai area dalam rongga mulut, dan dilepaskan secara perlahan, sehingga berfungsi sebagai antibakteri untuk waktu yang cukup lama. Efek bakterisid dari bahan ini berupa kerusakan intergritas sel dan presipitasi kandungan sitoplasmik.4,5

Selain keuntungan, klorheksidin juga memiliki kerugian berupa efek samping 
yang tidak diinginkan. Efek samping reversible akibat pemakaian obat kumur klorheksidin cukup bervariasi, tetapi diskolorisasi merupakan merupakan efek yang sering dikeluhkan dan dapat dianalisis secara objektif. Diskolorisasi terjadi berupa warna kuning kecoklatan pada sepertiga gingiva dan interproksimal gigi dan lidah, mukositis, peningkatan penumpukan plak dan kalkulus supragingiva, dan gangguan pengecapan sementara.3 Menurut McKenzie dkk, Greenstein dkk, dan Addy yang dikutip oleh Dalimunthe, 8 terjadinya staining diduga karena pengendapan sulfida besi akibat reaksi sulfur yang berasal dari kelompok protein tiol yang mengalami denaturasi dengan ion besi yang berasal dari makanan dan minuman.

Dosis yang dianjurkan untuk obat kumur klorheksidin adalah berkumur $10 \mathrm{ml}$ larutan klorheksidin $0,2 \%$ atau $15 \mathrm{ml}$ larutan klorheksidin $0,12 \%$ dua kali sehari selama satu menit. Mengingat efek samping yang bisa ditimbulkan oleh klorheksidin, maka pemakaian obat kumur ini terutama adalah untuk pemakaian jangka pendek setelah pencabutan gigi dan bedah periodontal. Sedangkan untuk pemakaian jangka panjangnya dapat direkomendasikan untuk meningkatkan kesehatan periodonsium pada pasien yang menggunakan peranti ortodonsi cekat, pada pasien yang memakai overdenture, pada pasien yang mendapat terapi imunosupresif dan kemoterapi lainnya, pada pasien dengan resiko terjadinya infeksi endokarditis.7

Campuran amonia kuartenari (CAK)

Bahan kationik ini telah digunakan selama lebih dari 50 tahun. Bahan yang paling umum digunakan adalah cetylperidinium chloride (CPC) yang digunakan pada konsentrasi 0,05\% (cepacol) dan kadang-kadang dengan domiphen chloride (scope), merupakan suatu kation dan berikatan dengan jaringan mukosa mulut tetapi tidak sekuat ikatan bisbiguanida.4,7

Bahan CPC memiliki aksi antibakteri dengan jalan mengikat dan menderesorbsi bakteri, akan tetapi tidak memiliki efek penghambat plak. Bahan ini bersama dengan bisbiguanides memiliki kecenderungan untuk berikatan dengan jaringan mulut. Hal ini disebabkan oleh karena ion positifnya sangat kuat. Namun meskipun perlekatan pertamanya sangat kuat, bahan ini dilepaskan dari ikatannya dalam rongga mulut jauh lebih cepat dibanding dengan klorheksidin, sehingga tidak seefektif klorheksidin.4 Bahan CAK memiliki efek samping yang sama dengan dengan klorheksidin, terutama bila digunakan dalam 
jangka waktu yang lama dan dengan konsentrasi tinggi. Adanya rasa terbakar dan kadang-kadang terjadi deskuamasi juga pernah dilaporkan.4 Jenis obat kumur ini yang dipasarkan di Indonesia adalah Ultrafresh (Konimex) dengan komposisi CPC $50 \mathrm{mg} / 100 \mathrm{ml}$ dan etanol $17 \mathrm{ml} / 100 \mathrm{ml}$, dan obat kumur Oral B yang komposisinya antara lain juga memiliki kandungan CPC.8

\section{Ekstrak tumbuhan - sanguinarine}

Sanguinarine saat ini banyak digunakan sebagai pasta gigi dan obat kumur sebagai bahan antiplak/gingivitis. Bahan ini mengandung purified sanguinaria extract $(\mathrm{SaE})$ yang diperoleh dari ekstraksi alkohol dari getah akar tanaman sanguinaria canadensis, yang digunakan sebagai bahan antiplak atau gingivitis. Formulasi terbaru mengandung ekstrak dengan konsentrasi $0,03 \%$ (ekuivalen dengan $0,01 \%$ sanguinarine), dan $2 \%$ zinc chloride untuk meningkatkan antiplaknya.4,9

Terdapat beberapa spekulasi yang menyatakan bahwa zinc chloride merupakan kontributor utama keefektifan sanguinarine. Hal ini berdasarkan penelitian yang berlangsung selama 6 bulan yang mengamati pemakaian produk sanguinarine 2 kali sehari selama 9 minggu. Hal ini diduga karena kemungkinan sangunarine dan zinc chloride yang terkandung dalam obat kumur memiliki efek aditif atau sinergis jika digunakan secara kombinasi. Oleh sebab itu dibutuhkan penelitian lebih lanjut untuk mengamati hipotesis ini.10

\section{Fluoride}

Fluor yang dipakai secara topikal telah terbukti dapat menghambat pembentukan asam oleh bakteri mikroorganisme plak. Fluor yang diberikan secara topikal ternyata tidak melekat secara stabil pada email, oleh karena itu dapat dengan mudah diserap oleh mikroorganisme plak sehingga dapat menyebabkan gangguan pada fungsi metabolisme mikroorganisme plak itu sendiri.11

Sejumlah penelitian jangka pendek menunjukkan bahwa stannium fluoride merupakan antiplak yang lebih efektif dibandingkan dengan sodium fluoride. Sebagian besar peneliti saat ini lebih memilih untuk menggunakan stannous fluoride $0,4 \%$ dalam bentuk gel dibandingkan sebagai obat kumur. Seorang peneliti melaporkan bahwa penurunan gingivitis dan daerah perdarahan dalam rongga mulut lebih baik pada gel stannium fluoride dangan gel natrium fluoride, pada pasien yang menggunakan gigitiruan lepasan atau cekat. 4 
Konsentrasi yang dianggap efektif untuk mengurangi karies adalah sodium fluorida $2 \%$, stannous fluoride $8-10 \%$. Meskipun demikian, kemampuan fluoride dalam mengurangi karies tidak boleh disamakan dengan kemampuannya dalam mengurangi gingivitis dan periodontitis. Hal ini ditunjukkan dengan tidak dianjurkannya pemakaian fluoride untuk mengurangi gingivitis oleh ADA. Perlu juga diketahui bahwa pemakaian stannous floride dapat menimbulkan stain, akan tetapi stain tersebut mudah dilepaskan. Contoh obat kumur yang mengandung fluoride adalah Sensodyne.4,11

\section{Povidon-iodine}

Povidon-iodine diklasifikasikan sebagai iodophor, dibuat dengan menambahkan polyvinyl-pyrrolidone dalam elemen iodin.5 Povidon-iodine merupakan bahan antimikroba yang aman, murah, mudah diperoleh, tidak menimbulkan iritasi, resistensi bakteri, toksisitas dan stain. Efek bakterisidalnya diperoleh dengan konsentrasi 5-10\%, serta tidak mengganggu proses penyembuhan. Cara kerja povidon-iodine adalah bereaksi kuat dengan ikatan ganda asam lemak tak jenuh pada dinding sel dan membran organel. Setelah povidon bereaksi dengan dinding sel, akan terbentuk pori sementara atau permanen yang menyebabkan hilangnya material sitoplasmik dan ada aktivitas enzim yang berikatan secara langsung dengan iodine. Povidon-iodine dapat menyebabkan koagulasi bahan inti sel tanpa menghancurkan dinding sel. Contoh obat kumur yang mengandung povidon-iodine antara lain Betadine, dan Isodine. 7,12

\section{Heksetidine}

Heksetidine adalah salah satu jenis obat kumur yang merupakan derivat piridin. Menurut beberapa peneliti, senyawa ini berkhasiat antibakteri dan anti protozoa serta bermanfaat untuk bakteri garam positif dan garam negatif. Contoh produk obat kumur jenis ini adalah Bactidol dan Hexadol.7,13

\section{PEMBAHASAN}

Penggunaan bahan-bahan kimia dalam praktek kedokteran gigi, telah diterima dan diakui manfaatnya. Hal tersebut sesuai dengan penelitian Alberto dkk yang dikutip oleh Rosmelita,2 yang menyatakan bahwa obat kumur dengan antiseptik dapat menurunkan jumlah mikroba sampai $97 \%$. Namun dengan begitu banyaknya pilihan yang tersedia di pasaran, menuntut para dokter gigi maupun konsumen memiliki acuan untuk memilih 
obat yang efektif. Menurut Dalimunthe, 8 keefektifan pemakaian obat kumur perlu ditinjau dari dari tiga aspek. Aspek pertama, apakah pemakaian obat kumur sendiri memang bermakna dalam meningkatkan keefektifan pembersihan secara mekanis. Aspek kedua, adalah jenis obat kumur mana yang dapat diandalkan. Aspek Ketiga, terlepas dari tingkat keefektifannya, adakah efek samping dari pemakaian obat kumur tersebut.

Obat antimikroba oral telah digunakan dalam berbagai formulasi selama bertahun-tahun untuk mengobati gingivitis. Secara umum, obat antimikroba cukup efektif dalam mereduksi plak dan gingivitis, tapi hanya sedikit efeknya terhadap periodontitis. Antimikroba yang ideal adalah yang dapat mencapai area yang sakit dan dapat bertahan di area tersebut untuk mencapai hasil yang diinginkan, tanpa menimbulkan resistensi bakteri atau kerusakan jaringan dalam rongga mulut.5 Sebagai tambahan harga produk tersebut cukup terjangkau dan nyaman digunakan.14 Karakteristik lain yang menjadi pertimbangan dalam memilih obat kemoterapeutik adalah toksisitas rendah, potensi tinggi, permeabilitas bagus, kemanjuran dan substansivitas yang asli.15 Sementara itu, ADA telah menetapkan syarat yaitu, obat tersebut dapat mereduksi plak dan inflamasi gingiva selama paling kurang enam bulan tanpa efek samping yang merugikan.5 Berdasarkan hal di atas, ADA telah merekomendasikan dua bahan kemoterapeutik untuk merawat gingivitis, yaitu klorheksidin diglukonat dan minyak esensial sebagai obat kumur.5

Apabila keefektifan klorheksidin dan campuran fenol-minyak esensial diperbandingkan, ternyata klorheksidin secara signifikan lebih efektif dalam hal menurunkan skor indeks plak, skor indeks gingiva dan pendarahan gingiva.16 Hasil penelitian lain terhadap sekelompok orang dewasa melaporkan bahwa obat kumur klorheksidin dan campuran fenol-minyak esensial yang dikumur 2 kali sehari selama 12 bulan tidak berbeda keefektifannya dalam mengurangi skor indeks plak dan kedalaman probing, tapi klorheksidin lebih efektif secara signifikan dalam menurunkan skor indeks gingiva dibandingkan campuran fenol-minyak esensial.17

\section{SIMPULAN}

Kebersihan mulut yang baik dan terpelihara dapat mengurangi plak pada permukaan gigi, sehingga akan mengurangi kemungkinan terjadinya gingivitis dan 
penyakit rongga mulut lainnya. Kondisi tersebut akan tercipta apabila dilakukan prosedur oral hygiene yang baik, yaitu dengan melakukan kontrol plak secara mekanis, misalnya dengan menyikat gigi dan dibantu dengan penggunaan bahan kimia, diantaranya dalam bentuk obat kumur.

Dari berbagai literatur dapat dikemukakan bahwa obat kumur yang mengandung klorheksidin dan campuran minyak essensial-phenol cukup efektif dalam menghambat plak dan gingivitis, dan ternyata kedua bahan kimia inilah yang mendapat legitimasi dari ADA sebagai antiplak/antigingivitis. Meskipun demikian, penggunaan obat kumur hanya merupakan prosedur tambahan, dan bukan prosedur pengganti dari pembersihan atau kontrol plak secara mekanis dengan sikat gigi serta pembersihan gigi secara mekanis lainnya.

\section{DAFTAR PUSTAKA}

1. Boel T. Daya antibakteri kombinasi triklosan dan zink sitrat dalam beberapa konsentrasi terhadap pertumbuhan Streptococcus mutans. Dentika Dent J 1999; 5(1): 7-16.

2. Rosmelita D, Prayitno SW. Efektifitas pengenceran chlorhexidine $0,2 \% 1: 1$ terhadap kasus gingivitis serta evaluasi diskolorisasi pada gigi (penelitian). J Kedokteran Gigi Indonesia. Edisi Khusus KPPIKG / FKG UI 2003; 10: 661-6.

3. Newman MG, Takey HH, Carranza FA. Carranza's clinical periodontology. 9th ed Philadelphia: WB Saunders Co; 2002.p. 651-74.

4. Committee on Research, Science and therapy. Chemical agents for control of plague and gingivitis. The Board of Trustees 1994: 1-7.

5. Rose LF, Mealey BL, Genco RJ, Cohen DW. Periodontics medicine, surgery, and implant. St. Louis: Mosby; 2004. p.277-85

6. Sudiono J. Pengaruh pemakaian obat kumur senyawa fenol terhadap gambaran SEM epitel mukosa bukal tikus. Majalah Ilmiah Kedokteran Gigi FKG USAKTI. 1998; 4; (38): 70-5.

7. Fischmen SL. Over-the- cunter muthrinses. J Calif Dent Assoc 1998.

8. Daliemunthe SH. Obat kumur dan kesehatan periodontium. Majalah Kedokteran Gigi USU 1998; 4: 17-22.

9. Harper DS, Mueller LJ, Fine JB, Gordon J, Laster LL. Effect of 6 months use of a dentifrice and oral rinse containing sanguinaria extract and zinc chloride upon the microflora 
of the dental plaque and soft tissues. $\mathbf{J}$ Periodontol 1990; 61(5): 359-63.

10. Harper DS, Mueller LJ, Fine JB, Gordon J, Laster LL. Clinical efficacy of a dentifrice and oral rinse containing sangunaria extract and zinc chloride during 6 month of use. J Periodontol 1990; 61(5): 351-8.

11. Panjaitan M. Efektifitas stannous fluoride dan natrium fluorida dalam menghambat pembentukan asam laktat. Majalah Kedokteran Gigi 1997; 30(2): 56-70.

12. Suwandi T. Efek klinis aplikasi subgingival racikan gel metronidazole $25 \%$ dan larutan povidon-iodine $10 \%$ sebagai terapi penunjang skelingpenghalusan akar pada periodontitis. J Kedokteran Gigi UI. Edisi Khusus KPPIKG, FKG UI 2003: 669-74.

13. Johan C. Efek kumur larutan hexetidine $1 \%$ sebelum pencabutan gigi terhadap terjadinya bakterimia setelah pencabutan gigi. J Kedokteran Gigi USAKTI 2000; 15(42):125-9

14. van der Ouderaa FJG. Anti-plaque agents. Rationale and prospects for prevention of gingivitis and periodontal disease. J Clin Periodontol 1991; 18: 447-54.
15. Goodson JM. Pharmacokinetic principles controlling efficacy of oral therapy. J Dent Res 1989; 68: 1625-32.

16. Grossman E, Meckel AH, Issacs RL, Ferretti GA, Sturzenberger OP, Bollmer BW etc. Clinical comparison of antibacterial mouthrinse: effects of chlorhexidine, phenolics, and sanguinarine on dental plaque and gingivitis. J Periodontol 1989; 8: 4359.

17. McKenzie WI, Forgas L, Vernio AR, Parker D, Emestall ED. Comparison of a $0.12 \%$ chlorhexidine mouthrinse and an essensial mouthrinse on oral health in institutionalized, mentally handicapped adults: one year results. J Periodontol 1992; 63: 187-93 